\title{
POLYSEMANTIC FEATURES OF PEDAGOGICAL TERMS IN ENGLISH AND UZBEK TRANSLATION
}

\author{
Nizomova Mohinur Baratboyevna \\ Teacher Of Karshi State University,Uzbekistan
}

\section{ABSTRACT}

The current state of scientific development of current problems of linguistics, the tasks of lexicology, the general development prospects of the theory of meaning and evaluation require the search for linguistic innovations, a new look at previous problems, and at the same time include current issues. Linguistics has been studied in a comparative way into the orbit of scientific research. The current stage of development of linguistics places the task of researchers to re-examine these issues on the basis of modern methods, one of which is the method of studying language materials as a specific system. This is because language and its layers are integrated with the layers as a whole, including the dictionary itself. Each dictionary is represented by its own layered system, because each word and, accordingly, each concept occupies a certain place in this system, which is determined by its relationship with other words and concepts.

KEYWORDS: - Lexemes, homonymous terms, synonymous terms, in polysemy,education, pedagogy, terms, institution, organization, learners,schools, features,semantic,language,grade;

\section{INTRODUCTION}

Historically, scientific and pedagogical knowledge in the world is associated with concepts that reflect the subject of pedagogical research (education in local pedagogy; education in the English-speaking pedagogical tradition) and cognitive activity itself, its ways develops in concepts and is a conceptual apparatus of world pedagogical science to build tools (teaching methods).

The lexical system of a language is not only the least studied, but also much more complex in terms of organization and structure. This system contains so many elements associated with different relationships that it is difficult or often questionable to imagine their structure. It contains irregular phenomena, the description of which requires many rules that are closely related to external, extralinguistic factors. This complexity is also characteristic of the microsystem of pedagogical terms, which is exacerbated when comparative research is conducted on the material of languages of different grammatical systems.

Comparative study of lexical materials of Uzbek and English languages and their interaction is of great theoretical and practical importance for further development of comparative typological study of different structural languages. does. Nowadays, the systematic method is increasingly used in the comparative study of languages in different grammatical systems, as well as languages with the same grammatical structure, which can be considered as one of the modern methods of linguistic research. However, it should be noted that this method is not always equally effective in the study of certain layers of language. In particular, the 
CURRENT RESEARCH JOURNAL OF PHILOLOGICAL SCIENCES 2(12):

21-25, December 2021

DOI: https://doi.org/10.37547/philological-crjps-02-12-05

ISSN 2767-3758

(C)2021 Master Journals

Crossref do

gil Google

Accepted05th December, 2021 \& Published $10^{\text {th }}$ December, 2021

systematic approach to the study of lexical material of a language is not always convenient, because the systematic study of lexical material is much more difficult than the materials of other layers of language.

"A.I. Comarova, on the other hand, did not study the terminology as a special aspect, but as a special lexicilla of a clear language system. " ${ }^{1}$ In fact, the emergence of new terms in special semantics is one way or another through language-specific simple, morphological, lexical-semantic, and word acquisition

occurs. Modern linguistics places great emphasis on understanding and learning language as a system. One of the basic principles of linguistics is a systematic approach to the study of language and its levels. The diversity of approaches to understanding the structure of language is, first and foremost, the complexity, versatility, inconsistency, and variability of the language system itself, its levels and units.

The peculiarities of the systematic-semantic organization of the terminological dictionary define the peculiarities of the comparative-typological study of terminology as a system of reflection of the conceptual structure of a particular field of science, which was initially system-oriented and rigidly structured. and is characterized by structural organization. The specificity of the expression of a particular system of scientific concepts determines the specifics of the functioning of terminology as a special semantic system in the dictionary. This term reflects the concepts of the fields of science. ${ }^{2}$

\footnotetext{
1 Абдуазизов А.А.Тилшуносликка кириш назарияси.-Т.: Шарқ , 2010.-Б. 14

${ }^{2}$ Nizomova M. B.“Classification of pedagogical terms in English and Uzbek language" Эканомика И сотциум . Nः 10(77) 2020 178-182- $\mathrm{p}$
}

1. Pedagogical terms related to a person. In the advanced languages in the field of pedagogy, the terms of the individual are divided into many of them into the types of types:

Learners-Ta'lim oluvchilar: o'quvchi-pupil, talabastudent, abutrent- abutrent;

Educators-Ta'lim beruvchilar: o'qituvchi- teacher; asistant- assistant; stajyor o'qituvchi- internship teacher; kata o'qituvchi-senior teacher; falsafa doktori- doctor of philosophy; fan doctori- doctor of science; professor- professor, dotsent- docent; Person involved in the activities and control of educational institutions; Ta'lim maskanlar faoliyati va nazorati bilan shug'illanuvchilar; Group coachguruh murabbiyi; tutor-sinf rahbar; deputy deandekan movunlari; dean-dekan; Head of the educational department-o'quv bo'limi boshlig'i; Head of the Scientific Department-ilmiy bo'lim boshlig'i; Vice-Rectors-prorektorlar; Rectorsrektorlar; Directors-direktorlar;

2. Pedagogical organizations and institutions are observed in both languages. These are primarily related to the education system. First of all, let's look at the education system in Uzbekistan and the institutions operating in it:

- maktabgacha ta'lim- preschool education; Maktabgacha ta'lim muassasasi- Preschool;

- umumiy o'rta ta'lim- general secondary education; $\mathrm{Bu}$ xalq ta'limiga qarashli maktabkar-Schools;

- maktabdan tashqari ta lim- extracurricular education; This includes schools, including children and adolescents, includes schools and instructions. Works closely with the school. In addition to school educational institutions palaces of children's and teenagers' creativity(bolalar, o'smirlar ijodiyoti saroylari), house(uylari), clubs and centers (klublari va markazlari), children and youth sports schools (bolalar-o'smirlar sport maktablari), art schools(san'at 
CURRENT RESEARCH JOURNAL OF PHILOLOGICAL SCIENCES 2(12):

21-25, December 2021

DOI: https://doi.org/10.37547/philological-crjps-02-12-05

ISSN 2767-3758

(C)2021 Master Journals

Crossref d

81 Google

Accepted05 ${ }^{\text {th }}$ December, 2021 \& Published 10 ${ }^{\text {th }}$ December, 2021

\begin{abstract}
maktablari),music schools (musiqa maktablari),studios(studiyalar), libraries (kutubxonalar), and other institutions include;

- o'rta maxsus kasb-hunar ta'limi- secondary special vocational education; O'MKHT-SSVE It is medium special professional schools;

- $\quad$ oliy ta'lim- higher education; Specialists with higher education -Institutlar Institutions and Universitetlar- Universities;

- $\quad$ oliy ta limdan keyingi ta`lim- postgraduate education; In institution agency, the doctor of philosophy (PhD), (fan doktori )-Doctor of Science;

- $\quad$ malaka oshirish va kadrlarni qayta tayorlashtraining and retraining; Institutions, and centers organized by universities, retraining and advanced training of pedagogical staff and public educators;
\end{abstract}

In the United States, education is carried out at the state, private and homes.

(davlat- public schools, xususiy- private schools va uy- home schools)

Preschool $^{3}$-maktabgacha ta'lim, Pre-kindergartenbolalar bog'chasi; For children aged 3-5;

America has 3 different educational systems:

Cumpulsory education-majburiy ta'lim; Higher education-oliy ta'lim; Continuing education uzluksiz ta'lim;

Compulsory education is carried out in schools and schools also consist of the following stages.

Elementary school- boshlang'ich maktab; Includes pupils from 5-6 to 5 classes, that is, until age 10-11; Middle school- O'rta maktab, Junior high school yoshi baland o'quvchilar maktabi For students from 6 to 8 th grade to 8-14 years of age;

3 Dictionary of Military Terms. - 3rd edition by Richard Bowyer. - London, 2007
High school is a senior high school-Freshman / 9th grade-9th grade (15-16 years old); Sophomore / 10th grade / Second course / 10th grade (15-16 years old); Junior / 11thgrade-11th grade (16-17 years old); senior / 12th grade-senior 12th grade (17-18 years old);

High school-yuqori maktab

senior high school-oliy darajali maktab

Freshman/ 9th grade-birinchi kurs talabasi/9 -sinf

Sophomore/10th grade-Ikkinchi kurs/10 -sinf

Junior/11thgrade-11-sinf

senior/12th grade-katta $12 \mathrm{sinf}$

Higher education consists of: College(University)Kollej,Undergraduate schoolbakalavr maktab, First year: "freshman year"Birinchi yil: "birinchi kurs";Second year: "sophomore year"-Ikkinchi yil: "ikkinchi kurs";Third year: "junior year"-Uchinchi yil: "kichik yil";Fourth year: "senior year"-To'rtinchi yil: "kata yil"(18-22yosh); Graduate school(with various degrees and curricular partitions thereof)Magistratura (with different levels and their academic departments);

There are 2 different forms of continuing education: Vocational education-Kasb -hunar ta'limi;(16yoshdan yuqori);Adult educationKattalar,ulg'ayganlar ta'limi;(18 yoshdan yuqori);

3. Terms related to teaching aids used in the educational process are important in the field of pedagogy and are constantly used for learning, teaching and its quality. They are:

Ta'lim jarayonida qo'llaniladigan texnik vositalartechnical means used in the educational process zamonaviy texnik vositalar (modern technical means)-kompyuter-coputer; super Kompyuterlar (Super Computer) blok Kompyuterlar (Manframe Computer); mini Kompyuterlar (MiniComputer);shaxsiy Kompyuterlar (PC- 
CURRENT RESEARCH JOURNAL OF PHILOLOGICAL SCIENCES 2(12):

21-25, December 2021

DOI: https://doi.org/10.37547/philological-crjps-02-12-05

ISSN 2767-3758

(C)2021 Master Journals

Crossref d

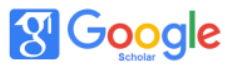

Accepted05 ${ }^{\text {th }}$ December, 2021 \& Published 10 ${ }^{\text {th }}$ December, 2021

Personal Computer); bloknot (Noutbook) Kompyuterlar. projektor- projector; smart bord;

Ta'lim jarayonida qo'llaniladigan o'quv qurollarikitoblar-books; daftar-nootebook; ruchka-pen; qalam-pencil; bord-doska; qog'oz- paper; pagevaroq; chizg'ich- ruler; o'chirg'ich- eraser; qo'llanmalari - tutorials; darsliklar- textbooks;

4. Examples of pedagogical terms related to the process are: O'quv jarayoni-study process; taxlil jarayoni- analysis process; o'rganish jarayonilearning process; o'rgatish jarayoni- teaching process; tajriba- experience; tarjima jarayonitranslating process; tahlil qilish jarayoni- analysis process; ta'lim jarayonidagi dasturlar- programs in education processes; baholash jarayoni- assesment process;

The following diagram compares the pedagogical terms related to the process and their classification: Abu Nasr praised Faroobi and called him "AlMuallim as-Sani" in the east.

"Al-Muallim as-Sani" - second teacher- (ya'ni Aristoteldan kiyingi ikkinchi muallim)

Farobi knew 70 world languages. It is safe to say that he was the founder of such concepts as grammar, logic, teaching, answering, and poetics. Addressing everyone, especially parents and teachers, he said: "How to teach and learn, how to express, express, ask and respond When it comes to teaching, I confirm that the first science is language, the second science is grammar, the third science is logic, and the fourth science is poetics" 4 .

Grammar - a branch that studies the laws of word formation, as well as the laws of word formation and sentence construction;( gramatika, ya'ni so'zlarning shaklga ega bo'lish qonuniyatlarini, shuningdek, so'z birikmalari va gaplarni tuzish qonuniyatlarini o'rganadigan bo'limi);

${ }^{4}$ O'zbekiston xalqi tarixi.T 'Fan',1992, 99-bet
Logic is a philosophical study of the principles of logic, reasoning, and inference;( mantiq, dalil keltirish va xulosa chiqarish prinsiplarini o'rganuvchi falsafiy tadqiqotdir);

to teach- to impart new knowledge and concepts to students in the context of pedagogical activity;( ta'lim bermoq,pedagoglik faoliyatidan kelib chiqqan holatda, o'quvchilarga yangi bilim va tushunchalar olib boorish;

to learn- learning, learning and analyzing new information;( ta'lim olish, yangi ma'lumotni o'rganish va tahlil qilish);

poetics-poetics; ( poetika)

answer- to answer; (javob bermoq);

In summary, the semantic analysis of pedagogical terms has seen comparable terms in the field of pedagogy and their integral connection in both languages and their use for the same purpose. It should be noted that the relationship between language and culture is lexical. There is a language because of the characters. Culture, on the other hand, is the meanings that emerge in language is a historical model of expression.The balance of language and culture is based on the following factors:

1. Language and culture - the human worldview in the context of the linguistic world are forms of reflective perception.

2. Language and culture are inextricably linked.

3. The subject of language and culture is always the person (individual) orsociety.

4. The emergence of both is historical, systematic, and characterized by normative substantiation.

5. Language and culture, on the one hand, always changing, on the other strives for stability on the part of.

Language and culture are the process of communication, as well as the individual and the whole is inextricably linked with the formation of 
CURRENT RESEARCH JOURNAL OF PHILOLOGICAL SCIENCES 2(12):

21-25, December 2021

DOI: https://doi.org/10.37547/philological-crjps-02-12-05

ISSN 2767-3758

(C)2021 Master Journals

Crossref d

Accepted05 ${ }^{\text {th }}$ December, 2021 \& Published 10 ${ }^{\text {th }}$ December, 2021

society. Harmony of language and culture

1) in the process of communication;

2) ontogeny - in the formation of human language skills;

3) phylogeny - manifested in the formation of hereditary and social personality will be. Language is an open system that develops selfdynamically.

The language is used by a large number of people. Alternatively, humanity has its own can not change the language at will, the language of their choice is their mother tongue cannot be selected as. Culture is associated with the active participation of humanity, it is created by humanity. New theories and realities of culture develops under the influence of new phenomena. In particular, the XXI century, which is considered to be the age of high technologies, is radically changing the culture, lifestyle, art, social structure, family relations and others. Language is the property of any human society, and it is only natural that it should change and evolve as a phenomenon.

In addition, language is an integral part of the culture inherited from ancestors, understanding and researching culture.Is also the main tool of doing. Only a deep understanding of science, religion, literature, the prevention of military conflicts and contradictions that arise it is the same truth that it is done through language, that is, through debates, negotiations, truces and agreements.

\section{REFERENCES}

1. Абдуазизов А.А.Тилшуносликка кириш назарияси.-Т.: Шарқ, 2010.-Б. 144.

2. Абдуллаев Ф. -чи аффиксининг генезисига доир//Ўзбек тили ва адабиёти. 1960, 6-сон. - Б. 47.; Валиев В. “Девону луғотит турк”да -чі аффиксининг от ясашига доир // Ўзбек тили ва адабиёти. 1964. 3-сон. - Б. 55.
3. Абдурахмонов муаммолари терминологияси ва унинг тараққиёт переспективалари: Биринчи Республика терминология конференцияси материаллари. -Т.: Фан, 1986. - Б. 136.

4. Nizomova M.B. "Classification of pedagogical terms in English and Uzbek language" Эканомика И сотциум . N: 10(77) 2020 178182- $\mathrm{p}$

5. Online Etimological Dictionary: https://www.etymonline.com/search?q= beleaguer

6. Online Etymology Dictionary. 2016. URL: http://etymonline.com 